SPARK 


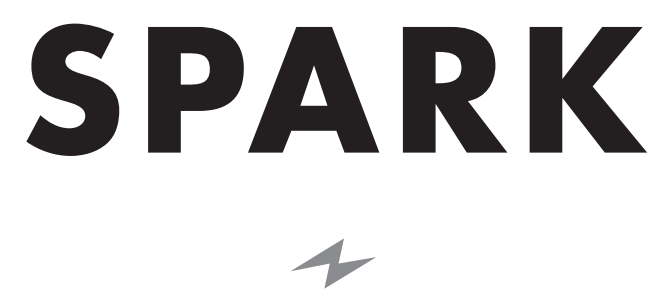

\section{THE LIFE OF ELECTRICITY AND THE ELECTRICITY OF LIFE}

TIMOTHY J. JORGENSEN 
Copyright (C) 2021 by Timothy J. Jorgensen

Princeton University Press is committed to the protection of copyright and the intellectual property our authors entrust to us. Copyright promotes the progress and integrity of knowledge. Thank you for supporting free speech and the global exchange of ideas by purchasing an authorized edition of this book. If you wish to reproduce or distribute any part of it in any form, please obtain permission.

Requests for permission to reproduce material from this work should be sent to permissions@press.princeton.edu

Published by Princeton University Press

41 William Street, Princeton, New Jersey o8540

6 Oxford Street, Woodstock, Oxfordshire OX20 1TR

press.princeton.edu

All Rights Reserved

Library of Congress Cataloging-in-Publication Data

Names: Jorgensen, Timothy J., author.

Title: Spark : the life of electricity and the electricity of life /

Timothy J. Jorgensen, Princeton University Press.

Description: Princeton : Princeton University Press, [2021] |

Includes bibliographical references and index.

Identifiers: LCCN 2021026499 (print) | LCCN 2021026500 (ebook) |

ISBN 9780691197838 (hardback) | ISBN 9780691232652 (ebook)

Subjects: LCSH: Electricity. | BISAC: SCIENCE / Physics / Electricity | SCIENCE / History

Classification: LCC QC527 .J66 2021 (print) | LCC QC527 (ebook)|

DDC 537 - dc23

LC record available at https://lccn.loc.gov/2021026499

LC ebook record available at https://lccn.loc.gov/2021026500

British Library Cataloging-in-Publication Data is available

Editorial: Ingrid Gnerlich, Maria Garcia, and Whitney Rauenhorst

Production Editorial: Natalie Baan

Production: Danielle Amatucci

Publicity: Kate Farquhar-Thomson and Sara Henning-Stout

Copyeditor: Jennifer McClain

\section{Doom and Gloom}

Words and Music by Mick Jagger and Keith Richards

Copyright (C) 2012 Promopub B.V.

All Rights Administered by BMG Rights Management (US) LLC

All Right Reserved. Used by Permission.

Reprinted by Permission of Hal Leonard LLC.

Jacket art and design by Sukutangan

This book has been composed in Arno

Printed on acid-free paper. $\infty$

Printed in the United States of America

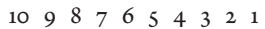


For my vivacious, bright, and beautiful wife, Helen. She gets the creditfor first proposing I write a book about electricity from a biological perspective, a creative idea for which I am very grateful. My life would be severely lacking without her unwavering love and devotion.

(What she sees in me I have no idea.) 
